\title{
Determination of Inorganic Elements Content and Distribution in Bamboo Shoots by Microwave Digestion and ICP-MS
}

\author{
Jianzhi Ye, Zipeng Su, Ling Lin, Yubing Zha, Mingyue Wang, Chunliang Yang* \\ Agricultural Product Processing Research Institute, Chinese Academy of Tropical Agricultural Sciences, \\ Zhanjiang, China \\ Email: "904506892@qq.com
}

Received 5 August 2016; accepted 23 August 2016; published 26 August 2016

Copyright (C) 2016 by authors and Scientific Research Publishing Inc.

This work is licensed under the Creative Commons Attribution International License (CC BY). http://creativecommons.org/licenses/by/4.0/

(c) (i) Open Access

\begin{abstract}
Microwave digestion and inductively coupled plasma mass spectrometry (ICP-MS) method was used to determine the contents of 25 inorganic elements in basal part, meat and shell of bamboo shoots. It could be concluded that the method could be applied to determine 25 inorganic elements in bamboo shoots. The elements with a dry basis content higher than $10 \mathrm{mg} / \mathrm{kg}$ were listed in the order of content decrease as follows, basal part of bamboo shoots: $\mathrm{K}>\mathrm{Ca}>\mathrm{Mg}>\mathrm{Mn}>\mathrm{P}>\mathrm{Al}>$ $\mathrm{Fe}>\mathrm{Zn}>\mathrm{Na}$; bamboo shoots meat: $\mathrm{K}>\mathrm{P}>\mathrm{Ca}>\mathrm{Mg}>\mathrm{Mn}>\mathrm{Fe}>\mathrm{Al}>\mathrm{Zn}>\mathrm{Na}>\mathrm{Ba}>\mathrm{Sr}$; bamboo shoots shell: $\mathrm{K}>\mathrm{P}>\mathrm{Mg}>\mathrm{Ca}>\mathrm{Mn}>\mathrm{Al}>\mathrm{Fe}>\mathrm{Na}>\mathrm{Zn}$; $\mathrm{B}, \mathrm{Pb}, \mathrm{Cu}, \mathrm{Cr}$ ranged from $1.0-10 \mathrm{mg} / \mathrm{kg}$; Ga, As, Se, Cd, Sn, Sb, V, Co, Ni were lower than $0.80 \mathrm{mg} / \mathrm{kg}$. The harmful elements Cd, As, Cr, Hg, Pb were commonly monitored in feeds. The wet basis content $(\mathrm{mg} / \mathrm{kg})$ of $\mathrm{Cd}, \mathrm{As}, \mathrm{Cr}$ was lower than: $0.028,0.022$ and 0.42 respectively; no $\mathrm{Hg}$ was found; the content of $\mathrm{Pb}(\mathrm{mg} / \mathrm{kg})$ in basal part, meat and shell of bamboo shoots was $0.82,0.35$ and 0.41 respectively. The results provide basic data for the development of bamboo shoots and its byproduct.
\end{abstract}

\section{Keywords}

Bamboo Shoots, Basal Part of Bamboo Shoots, Bamboo Shoots Meat, Bamboo Shoots Shell, Inorganic Element

\section{Introduction}

China is the world's main bamboo producing country, and the production of bamboo shoots is leading in the world. The production in Fujian, Zhejiang, Jiangxi and Hunan Province is the highest. About $40 \%$ of bamboo

${ }^{*}$ Corresponding author.

How to cite this paper: Ye, J.Z., Su, Z.P., Lin, L., Zha, Y.B., Wang, M.Y. and Yang, C.L. (2016) Determination of Inorganic Elements Content and Distribution in Bamboo Shoots by Microwave Digestion and ICP-MS. Journal of Agricultural Chemistry and Environment, 5, 152-157. http://dx.doi.org/10.4236/jacen.2016.53016 
shoots are sold fresh. Others are made into boiled canned bamboo shoots, dried bamboo shoots, sour bamboo shoots and various soft-packing or canned condiments [1]. Processing by-products of bamboo shoots are also continuously developed and utilized. The bamboo shoot shell is rich in phytosterol, amino acids, polysaccharide, flavonoids and other bioactive substances [2]. Cellulose, hemicelluloses, lignin and others can also be separated from them [3] [4]. Bamboo shoot shells can be also made into the "nutritious diets" [5]. Sun Jingya et al. [6] extracted the brown pigment with the special odor of bamboo shoots from bamboo shoot shells and used as additives for the food industry. The application prospect is broad. The basal part accounts for $31 \%$ of the total weight of fresh bamboo shoots. It is rich in dietary fiber, $\beta$-sitosterol, etc. Now there are a lot of studies related to the extraction [7] [8]. Many inorganic mineral elements are beneficial to human health. Most of them exist in the human body in the form of complex, convey various substances necessary to life, and adjusting human body's metabolism [9]. A few toxic metal elements, such as chromium, nickel, arsenic, lead, cadmium and mercury, have carcinogenicity. The intake of some elements has a safe and suitable scope. Outside this scope, they will be harmful to the body [10]. Take Se as an example. Lack of Se may cause epidermal keratinization of human body and cancer, but excessive intake can cause poisoning [11]. So understanding the content of inorganic elements in bamboo shoots and its by-products provides the basis for development of food, medicine, etc.

At present, a number of studies on the organic components of bamboo shoots and its by-products from processing have been reported [12]-[15]. Because of the limitation of detection means, the attention to inorganic element is not comprehensive enough [16]. ICP-MS is a kind of analysis and test technology developed in the 1980s. Through the unique interface, it combines the high temperature ionization of ICP and sensitive and rapid scanning of MS, and forms a new kind of multi-element and isotope analysis method. The method can test elements with the mass number of 6 - 260 at the same time. The linear dynamic range of concentration has nine orders of magnitudes, and various elements with big content difference can be measured at the same time.

Thus, it quickly became an important tool of elemental analysis [17] [18]. This experiment adopts the method of microwave digestion and ICP_MS, and determines the content of 25 kinds of inorganic elements in basal part, meat and shell of bamboo shoots at the same time.

\section{Materials and Methods}

\subsection{Instrument and Equipment}

ICP-MS (ThermoFisher Scientific X series II, USA), microwave digestion instrument (CEM MARS, USA), ultrapure water generator (Milli-Q Element, Millipore, France), digestion instrument (Annan DV4000, Beijing).

\subsection{Test Materials and Reagents}

Bamboo shoots: Longyan in Fujian Province.

Guaranteed reagent of $\mathrm{HNO}_{3}$ (65\%), Germany Merck; guaranteed reagent of $\mathrm{H}_{2} \mathrm{O}_{2}$ (30\%), Germany Merck; high purity argon with the purity of 99.999\%; mixture of hydrogen and helium (high-purity, containing $7.12 \%$ of hydrogen); ultrapure water as the experiment water (18.2 M $\Omega$ ); mixed tuned liquid of $\mathrm{Li}$, Co, In and $\mathrm{U}$ of 10 $\mathrm{mg} / \mathrm{L}$, O2si of the United States; $1000 \mathrm{mg} / \mathrm{L}$ of Re, National Center of Analysis and Testing for Nonferrous Metals and Electronic Materials; B, Na, Mg, Al, Ca, P, K, Ca, V, Cr, Mn, Co, Ni, Cu, Zn, Ga, As, Sr, Cd, Ba, $\mathrm{Hg}, \mathrm{Pb}, \mathrm{Fe}, \mathrm{Se}, \mathrm{Ge}$, In and Rh of $1000 \mathrm{mg} / \mathrm{L}$, Iron \& Steel Research Institute of China National Center for Quality Supervision and Testing of Iron and Steel; Sn and Sb of $500 \mathrm{mg} / \mathrm{L}$, Iron \& Steel Research Institute of China National Center for Quality Supervision and Testing of Iron and Steel; Au of $100 \mu \mathrm{g} / \mathrm{g}$, National Institute of Metrology, China; and Tea Leaves GBW10016, Geophysical and Geochemical Prospecting Institute.

\subsection{Method}

\subsubsection{Sample Treatment Method}

Each part of the bamboo shoot was taken. $0.25 \mathrm{~kg}$ of wet material was taken from each part with the cross quartering method, dried at $60^{\circ} \mathrm{C}$, crushed and sieved with 40 -mesh screen. $0.50 \mathrm{~g}$ of sieved sample was accurately weighed and placed into the digestion tank. $6.0 \mathrm{~mL}$ of $\mathrm{HNO}_{3}, 2.0 \mathrm{~mL}$ of $\mathrm{H}_{2} \mathrm{O}_{2}$ and $0.02 \mathrm{~mL}$ of Au standard liquid was added. After the same treatment of standard substance, $0.200 \mathrm{ml}$ of $\mathrm{Ga}$, Sn and $\mathrm{Hg}$ intermediate liquid (1000 ug/L) was added, respectively. It was digested for $2 \mathrm{~h}$ at $90^{\circ} \mathrm{C}$, cooled to room temperature, capped, sealed, and digested with microwave. The digestion conditions are shown in Table 1. Six parallel samples and blank 
samples were made for every part sample, standard substance and adding standard sample.

\subsubsection{ICP-MS Work Conditions}

In the startup optimization, the signal value of $\mathrm{Li}$, Co, In and $\mathrm{U}$ was adjusted to the maximum. Double charge and oxide interference was reduced to the value below 3.0\%. The sampling depth was $150 \mathrm{~mm}$. It was $16 \mathrm{~mm}$ horizontally and $285 \mathrm{~mm}$ vertically. The rate of cooling air was $13.02 \mathrm{~L} / \mathrm{min}$, that of auxiliary gas was $0.8 \mathrm{~L} / \mathrm{min}$, and that of atomization gas was $0.93 \mathrm{~L} / \mathrm{min}$. When the CCTS technology was used, the mixed gas was hydrogen + helium with the rate of 7:93. The gas flow rate was $4.5 \mathrm{~mL} / \mathrm{min}$. Float mode was used for high-content and high-sensitivity elements. Each element was scanned for 100 times. The hold time was $10 \mathrm{~ms}$. There were 3 channels. The channel spacing was 0.02 AMU.

\section{Results and Analysis}

\subsection{The Selection of Isotope and Interference Correction}

In ICP-MS analysis, by the selection of appropriate isotope of element to be tested, equation correction or CCTS technology, mass spectrum interference can be prevented to the greatest extent. The isotope of each element to be tested includes ${ }^{11} \mathrm{~B},{ }^{23} \mathrm{Na},{ }^{24} \mathrm{Mg},{ }^{27} \mathrm{Al},{ }^{31} \mathrm{P},{ }^{39} \mathrm{~K},{ }^{44} \mathrm{Ca},{ }^{451} \mathrm{~V},{ }^{52} \mathrm{Cr},{ }^{55} \mathrm{Mn},{ }^{56} \mathrm{Fe},{ }^{59} \mathrm{Co},{ }^{60} \mathrm{Ni},{ }^{65} \mathrm{Cu},{ }^{66} \mathrm{Zn},{ }^{69} \mathrm{Ga},{ }^{75} \mathrm{As}$, ${ }^{80} \mathrm{Se},{ }^{88} \mathrm{Sr},{ }^{111} \mathrm{Cd},{ }^{118} \mathrm{Sn},{ }^{121} \mathrm{Sb},{ }^{137} \mathrm{Ba},{ }^{202} \mathrm{Hg}$ and ${ }^{208} \mathrm{~Pb} .{ }^{80} \mathrm{Se}$ is corrected with CCTS technology [19]. Co and Ni are corrected with the following equation. $\mathrm{Co}={ }^{59} \mathrm{Co}-\left[0.001 \times{ }^{43} \mathrm{Ca}\right], \mathrm{Ni}={ }^{60} \mathrm{Ni}-\left[0.003 \times{ }^{43} \mathrm{Ca}\right]$ [17].

In order to overcome the sample matrix effect and other influences, the mixed internal standard of $\mathrm{Ge}, \mathrm{Rh}, \mathrm{In}$ and Re was added for correction of results.

$\mathrm{Hg}^{2+}$ has strong adsorption ability. To reduce the effect of memory effect on the results, when ICP-MS was used to measure the content of $\mathrm{Hg}, 0.02 \mathrm{~mL}$ of Au was added into the sample [20].

To protect the detector, according to the content of elements and sensitivity, Ca, Mg, AL, Na, P, K, V, Cr, Mn, $\mathrm{Sr}$ and Fe was measured with float mode and high resolution.

\subsection{Work Curve and the Detection Limit}

$\mathrm{Ca}, \mathrm{Mg}, \mathrm{Al}, \mathrm{Na}, \mathrm{P}, \mathrm{K}, \mathrm{V}, \mathrm{Cr}, \mathrm{Mn}, \mathrm{Sr}$ and Fe were used to prepare a set of mixed standard solution. B, Co, Ni, $\mathrm{Cu}$, $\mathrm{Zn}, \mathrm{Ga}, \mathrm{As}, \mathrm{Cd}, \mathrm{Sn}, \mathrm{Sb}, \mathrm{Ba}, \mathrm{Hg}$ and $\mathrm{Pb}$ were used to prepare a set of mixed standard solution. Se was used to prepare a set of standard solution alone. Work curve of each element consists of evenly spaced 6 concentration values from 0 to the highest concentration. The highest concentration is shown in Table 2.

Blank solution was determined for 10 times. The concentration corresponding to the three times of standard deviation is the detection limit of the method. Linear range, correlation coefficient and detection limit of the method are shown in Table 2.

\subsection{Accuracy and Precision of the Method}

To verify the accuracy and reliability of this method, according to the experimental steps and operating conditions selected, Tea Leaves GBW10016, the national standard substance, was determined. The results are shown in Table 3. The measured values are within the scope of the standard value. The recovery rate of $\mathrm{Ga}, \mathrm{Sn}$ and $\mathrm{Hg}$ is between $95.0 \%$ and $106.5 \%$. RSD is between $1.1 \%$ and $6.3 \%$. It proves that the method meets the requirements.

\subsection{Test Results are Shown in Table 4}

To detect bamboo shoot, bamboo shoots meat, bamboo in the content of inorganic elements using this method, the results are shown in Table 4.

Table 1. Working procedure of microwave digestion.

\begin{tabular}{cccccc}
\hline Step & Power $(\mathrm{W})$ & Emission rate (\%) & Heating up time $(\mathrm{min})$ & Temperature $\left({ }^{\circ} \mathrm{C}\right)$ & Hold time $(\mathrm{min})$ \\
\hline 1 & 1600 & 100 & 5 & 120 & 3 \\
2 & 1600 & 100 & 3 & 150 & 3 \\
3 & 1600 & 100 & 3 & 180 & 15 \\
\hline
\end{tabular}


Table 2. Linear range, correlation coefficient and detection limit of each element.

\begin{tabular}{cccccccc}
\hline Element & $\begin{array}{c}\text { Linear range } \\
(\mu \mathrm{g} / \mathrm{L})\end{array}$ & $\begin{array}{c}\text { Correlation } \\
\text { coefficient }\end{array}$ & $\begin{array}{c}\text { Detection limit } \\
(\mu \mathrm{g} / \mathrm{L})\end{array}$ & Element & $\begin{array}{c}\text { Linear range } \\
(\mu \mathrm{g} / \mathrm{L})\end{array}$ & $\begin{array}{c}\text { Correlation } \\
\text { coefficient }\end{array}$ & $\begin{array}{c}\text { Detection limit } \\
(\mu \mathrm{g} / \mathrm{L})\end{array}$ \\
\hline $\mathrm{B}$ & $0-100$ & 0.9997 & 0.23 & $\mathrm{Cu}$ & $0-100$ & 0.9997 & 0.40 \\
$\mathrm{Na}$ & $0-5000$ & 0.9978 & 4.3 & $\mathrm{Zn}$ & $0-100$ & 0.9998 & 1.6 \\
$\mathrm{Mg}$ & $0-2500$ & 0.9988 & 1.0 & $\mathrm{Ga}$ & $0-10$ & 1.0000 & 0.0081 \\
$\mathrm{Al}$ & $0-2000$ & 0.9983 & 1.2 & $\mathrm{As}$ & $0-100$ & 1.0000 & 0.030 \\
$\mathrm{P}$ & $0-10000$ & 0.9999 & 12 & $\mathrm{Se}$ & $0-10$ & 0.9996 & 0.20 \\
$\mathrm{~K}$ & $0-2500$ & 0.9998 & $1.6 \times 10^{2}$ & $\mathrm{Sr}$ & $0-100$ & 0.9998 & 0.015 \\
$\mathrm{Ca}$ & $0-10,000$ & 0.9993 & 40 & $\mathrm{Cd}$ & $0-10$ & 0.9999 & 0.0023 \\
$\mathrm{~V}$ & $0-100$ & 0.9994 & 0.019 & $\mathrm{Sn}$ & $0-10$ & 0.9999 & 0.026 \\
$\mathrm{Cr}$ & $0-100$ & 0.9996 & 0.095 & $\mathrm{Sb}$ & $0-10$ & 1.0000 & 0.0065 \\
$\mathrm{Mn}$ & $0-1000$ & 0.9994 & 0.26 & $\mathrm{Ba}$ & $0-100$ & 0.9996 & 0.069 \\
$\mathrm{Fe}$ & $0-1000$ & 0.9994 & 1.9 & $\mathrm{Hg}$ & $0-10$ & 0.9996 & 0.088 \\
$\mathrm{Co}$ & $0-10$ & 1.0000 & 0.0033 & $\mathrm{~Pb}$ & $0-100$ & 1.0000 & 0.028 \\
$\mathrm{Ni}$ & $0-100$ & 0.9996 & 0.20 & & & & \\
\hline
\end{tabular}

Table 3. Accuracy and precision of the method $(n=6)$.

\begin{tabular}{|c|c|c|c|c|c|c|c|}
\hline Element & $\begin{array}{l}\text { Standard value } \\
(\mathrm{mg} / \mathrm{kg})\end{array}$ & $\begin{array}{l}\text { Measured value } \\
\quad(\mathrm{mg} / \mathrm{kg})\end{array}$ & RSD (\%) & Element & Standard value (mg/kg) & $\begin{array}{l}\text { Measured value } \\
(\mathrm{mg} / \mathrm{kg})\end{array}$ & $\begin{array}{l}\text { RSD } \\
(\%)\end{array}$ \\
\hline B & $14 \pm 1$ & 13.5 & 3.2 & $\mathrm{Cu}$ & $18.6 \pm 0.7$ & 18.9 & 4.0 \\
\hline $\mathrm{Na}$ & $90 \pm 10$ & 85.0 & 5.2 & $\mathrm{Zn}$ & $51 \pm 2$ & 52.9 & 2.1 \\
\hline $\mathrm{Mg}$ & $1860 \pm 110$ & 1728 & 4.8 & As & $0.09 \pm 0.01$ & 0.098 & 5.1 \\
\hline $\mathrm{Al}$ & $940 \pm 90$ & 970 & 6.3 & Se & $0.098 \pm 0.008$ & 0.102 & 3.9 \\
\hline $\mathrm{P}$ & $4500 \pm 300$ & 4720 & 4.4 & $\mathrm{Sr}$ & $9.1 \pm 1.2$ & 10.0 & 1.1 \\
\hline $\mathrm{K}$ & $16,300 \pm 700$ & 16,900 & 3.1 & $\mathrm{Cd}$ & $0.062 \pm 0.004$ & 0.062 & 1.1 \\
\hline $\mathrm{Ca}$ & $3260 \pm 80$ & 3310 & 3.7 & $\mathrm{Sb}$ & $0.022 \pm 0.006$ & 0.019 & 3.1 \\
\hline $\mathrm{V}$ & $0.17 \pm 0.03$ & 0.20 & 2.4 & $\mathrm{Ba}$ & $9.6 \pm 0.5$ & 9.2 & 4.7 \\
\hline $\mathrm{Cr}$ & $0.45 \pm 0.10$ & 0.53 & 1.9 & $\mathrm{~Pb}$ & $1.5 \pm 0.2$ & 1.7 & 3.2 \\
\hline Mn & $500 \pm 20$ & 485 & 2.1 & Element & $\begin{array}{l}\text { Standard adding value } \\
\text { (mg/kg) }\end{array}$ & $\begin{array}{l}\text { Recovery rate } \\
\text { (\%) }\end{array}$ & $\begin{array}{l}\text { RSD } \\
(\%)\end{array}$ \\
\hline $\mathrm{Fe}$ & $242 \pm 18$ & 243 & 2.4 & Ga & 0.410 & 103.3 & 3.0 \\
\hline Co & $0.22 \pm 0.02$ & 0.23 & 1.2 & Sn & 0.410 & 106.5 & 4.4 \\
\hline $\mathrm{Ni}$ & $3.4 \pm 0.3$ & 3.11 & 2.7 & $\mathrm{Hg}$ & 0.410 & 95.0 & 4.7 \\
\hline
\end{tabular}

Table 4. Content of inorganic element in each part of bamboo shoots.

\begin{tabular}{|c|c|c|c|c|c|c|c|}
\hline Element & Basal part & Meat & Shell & Element & Basal part & Meat & Shell \\
\hline $\mathrm{K}(\mathrm{g} / \mathrm{kg})$ & 27 & 35 & 9.9 & B (mg/kg) & 1.8 & 2.1 & 0.92 \\
\hline Ca (g/kg) & 0.83 & 2.9 & 0.39 & $\mathrm{Cr}(\mathrm{mg} / \mathrm{kg})$ & 1.8 & 1.1 & 2.0 \\
\hline $\mathrm{Mg}(\mathrm{g} / \mathrm{kg})$ & 0.73 & 1.3 & 0.43 & Sb (ng/kg) & 0.73 & 1.8 & 1.5 \\
\hline Mn (g/kg) & 0.35 & 0.34 & 0.065 & $\mathrm{Ni}$ (mg/kg) & 0.52 & 0.80 & 0.22 \\
\hline$P(g / k g)$ & 0.22 & 4.4 & 0.75 & $\mathrm{Ga}(\mathrm{mg} / \mathrm{kg})$ & 0.39 & 0.73 & 0.084 \\
\hline $\mathrm{Al}$ (g/kg) & 0.19 & 0.080 & 0.057 & V (mg/kg) & 0.25 & 0.14 & 0.065 \\
\hline $\mathrm{Fe}(\mathrm{g} / \mathrm{kg})$ & 0.13 & 0.092 & 0.050 & Cd (mg/kg) & 0.12 & 0.14 & 0.019 \\
\hline Zn (mg/kg) & 44 & 60 & 10 & Se (mg/kg) & 0.11 & 0.21 & 0.032 \\
\hline $\mathrm{Na}(\mathrm{mg} / \mathrm{kg})$ & 22 & 26 & 22 & As (mg/kg) & 0.095 & 0.13 & 0.039 \\
\hline Ва (mg/kg) & 9.9 & 20 & 1.8 & Co (mg/kg) & 0.056 & 0.040 & 0.055 \\
\hline $\mathrm{Sr}(\mathrm{mg} / \mathrm{kg})$ & 5.9 & 16 & 1.2 & Sn (mg/kg) & - & 0.058 & 0.025 \\
\hline $\mathrm{Cu}$ (mg/kg) & 5.0 & 6.9 & 2.3 & Hg (mg/kg) & - & - & - \\
\hline $\mathrm{Pb}$ (mg/kg) & 5.0 & 4.2 & 2.9 & & & & \\
\hline
\end{tabular}

“_”: not detected. Detection limit of $\mathrm{Hg}: 0.0088 \mathrm{mg} / \mathrm{kg}$, detection limit of Sn: $0.003 \mathrm{mg} / \mathrm{kg}$. 
Table 5. Wet base content of harmful element (mg/kg).

\begin{tabular}{cccccc}
\hline & $\mathrm{Pb}$ & $\mathrm{Cd}$ & $\mathrm{As}$ & $\mathrm{Cr}$ & $\mathrm{Hg}$ \\
\hline Basal part & 0.82 & 0.028 & 0.022 & 0.42 & - \\
Meat & 0.35 & 0.017 & 0.015 & 0.13 & - \\
Shell & 0.41 & 0.0039 & 0.0079 & 0.41 & - \\
\hline
\end{tabular}

The method can meet the testing requirements; the ranking of content of inorganic element above $10 \mathrm{mg} / \mathrm{kg}$ is as follows. Basal part: $\mathrm{K}>\mathrm{Ca}>\mathrm{Mg}>\mathrm{Mn}>\mathrm{P}>\mathrm{Al}>\mathrm{Fe}>\mathrm{Zn}>\mathrm{Na}$; meat: $\mathrm{K}>\mathrm{P}>\mathrm{Ca}>\mathrm{Mg}>\mathrm{Mn}>\mathrm{Fe}>\mathrm{Al}>$ $\mathrm{Zn}>\mathrm{Na}>\mathrm{Ba}>\mathrm{Sr}$; shell: $\mathrm{K}>\mathrm{P}>\mathrm{Mg}>\mathrm{Ca}>\mathrm{Mn}>\mathrm{Al}>\mathrm{Fe}>\mathrm{Na}>\mathrm{Zn}$; the elements whose content in each part is 1.0 - $10 \mathrm{mg} / \mathrm{kg}$ include $\mathrm{B}, \mathrm{Pb}, \mathrm{Cu}$, Cr, etc. The content of $\mathrm{Ga}$, As, Se, Cd, Sn, Sb, V, Co and Ni are below 0.80 $\mathrm{mg} / \mathrm{kg}$.

Rich $\mathrm{Na}, \mathrm{K}$ and other elements which can maintain water in human body and constant $\mathrm{pH}$ of body fluid are contained. Ca content in meat of bamboo shoots is as high as $2.9 \times 10^{3} \mathrm{mg} / \mathrm{kg}$. The content of Fe, Zn, Mn and other essential microelements of human body is $(10-3.5) \times 10^{2} \mathrm{mg} / \mathrm{kg}$. The basal part and shall of bamboo shoots can be selectively developed into main feed of livestock. Se is the element drawing the most attention in the environment and health research field. Its content in each part of the bamboo shoots is above $0.032 \mathrm{mg} / \mathrm{kg}$. Se content in the meat of bamboo shoots meat is $0.21 \mathrm{mg} / \mathrm{kg}$.

Water content of basal part, meat and shell of bamboo shoots is $76.46 \%, 88.12 \%$ and $79.72 \%$ respectively. The calculated wet base content of $\mathrm{Pb}, \mathrm{Cd}$, As, Cr and Hg are shown in Table 5.

Harmful elements often monitored in food and feed include $\mathrm{Cd}$, As, Cr, $\mathrm{Hg}, \mathrm{Pb}$, etc. The wet base content of $\mathrm{Cd}$, As and Cr (mg/kg) is below 0.028, 0.022 and 0.42, respectively. Hg was not detected. The wet base content of $\mathrm{Pb}$ in meat, basal part and shell of bamboo shoots $(\mathrm{mg} / \mathrm{kg})$ is $0.82,0.35$ and 0.41 , respectively. According to the standard in the strict GB 2762-2012 Maximum Limit of Contaminants in Food, the content of Pb is a little higher. When it is developed into food, this should be considered. According to GB13078-2001 Feed Hygiene Standard, all raw materials for feed are safe.

\section{Conclusion}

In this paper, microwave digestion and ICP-MS method is used to measure the content of 25 kinds of inorganic elements, namely Ca, Mg, Al, Na, P, K, V, Cr, Mn, Sr, Co, Ni, Cu, Fe, B, zinc, Ga, As, Cd, Sn, Sb, Ba, Hg, Pb and Se. By measuring the national standard substance and the standard addition recovery test, the results show that the method can meet the testing requirements. Meanwhile, it tests the distribution 25 kinds of elements in bamboo shoot, bamboo shoots meat, bamboo and provides the basic data for the comprehensive utilization.

\section{Fund}

Dissimilarity Evaluation of the characteristics of the nutrient components of the plant derived agricultural products from different producing area, different growing period, different storage and fresh keeping and different consumption patterns (GJFP201601503).

\section{References}

[1] Shi, Q.T. (2003) The Current Situation and Development Prospect of Processing and Utilization of Bamboo Shoots in China. Journal of Bamboo Research, 22, 1-5.

[2] Yu, N.F. and Wang, Y. (2010) The Progress of Development and Utilization of the Shell of Bamboo Shoots in China. Jiangxi Forestry Science and Technology, 2010, 51-53.

[3] Xie, T. and Chen, P. (2008) Research on the Combination and Separation Technology of Fiber Components in the Shell of Bamboo Shoots. Journal of Hunan Institute of Engineering, 18, 72-75.

[4] Feng, G.F., Xie, T., Fu, X.H., et al. (2008) The Optimization of Saccharification Process of Fiber of Shell of Bamboo Shoots after Acid Treatment. Journal of Hunan Institute of Engineering, 19, 84-86.

[5] Wang, X.Q. and Liu, J.X. (1999) The Influence of Adding Straw and Bran Compound Silage into Shell of Bamboo Shoots on Fermentation Quality and Feeding Value of Silage. Journal of Animal Nutrition, 11, 53-55.

[6] Xie, B.X., Zhong, H.Y., Xie, T., et al. (2000) Research on the Development and Main Functions of Dietary Fiber in 
Bamboo Shoots. Economic Forest Researches, 19, 8-11.

[7] Li, Y.H., Zhang, S.Y., Lai, P.F., et al. (2010) Research on Preparing Water Soluble Dietary Fiber of the Basal Part of Bamboo Shoots with the Composite Enzyme Method. Science and Technology of the Food Industry, 31, $269-275$.

[8] Lv, G.T., Lin, L.J., Zhu, B.Q., et al. (2012) The Comparative Study of Different Extraction Methods of $\beta$-Sitosterol in the Basal Part of Moso Bamboo Shoots. Journal of Agricultural Machinery, 9, 111-114.

[9] Xing, R.L., Wang, C.H., Tang, N., et al. (2007) Analysis on the Content of Mineral Elements in Cells of Marine Benthic Diatom. Spectroscopy and Spectral Analysis, 27, 2131-2133.

[10] Xia, M. (2003) Physiological Functions of Necessary Trace Elements. Journal of Trace Elements and Health Research, 20, 41-44.

[11] Wang, Y., Tie, M., Kang, P.L., et al. (2009) Comparison of Three Methods and for the Determination of Selenium Content in Cordyceps militaris including ICP-MS. Spectroscopy and Spectral Analysis, 29, 815-818.

[12] Lin, L.J., Li, J.H., Zhu, D.M., et al. (2012) The Research on Ultra-fine Powder Nutritional Ingredient in the Basal Part of Moso Bamboo Shoots. Science and Technology of the Food Industry, 20, 328-329.

[13] Jia, Y.F. and Wang, W.Y. (2011) Chemical Composition and Cellulose Characteristics of Several Kinds of Shell of Bamboo Shoots. Journal of Zhejiang University (Agriculture and Life Science Edition), 37, 338-342.

[14] Chen, Y.H., Liu, C., Wang, W.J., et al. (1997) Research on Nutritional Ingredients of 12 Kinds of Moso Bamboo Shoots in Yunnan. Journal of Research and Development of Natural Products, 10, 25-30.

[15] Liu, L., Lin, X.C., Sun, P.J., et al. (2005) Analysis on Nutritional Ingredients of Bitter Bamboo Shoots and Leaves. Journal of Bamboo Research, 24, 15-18.

[16] Li, R., Wu, L.R., Zhou, C.P., et al. (2007) The Research on Nutritional Ingredients of Mineral Elements of Square Bamboo Shoots. Journal of Bamboo Research, 26, 37-39.

[17] Liu, H.W., Qin, Z.H., Xie, H.L., et al. (2013) The Determination of 28 Kinds of Inorganic Elements in Sunflower Seeds with ICP-OES/ICP-MS. Spectroscopy and Spectral Analysis, 33, 224-226.

[18] Hu, Q.Y., Li, L., Shi, J., et al. (2007) The Determination of 27 Kinds of Elements in Tobacco with Microwave Digestion and Inductively Coupled Plasma Mass Spectrometry Method. Spectroscopy and Spectral Analysis, 27, 1210-1213.

[19] Huang, X.W., Zhang, N. and Huang, X.L. (2009) Research on the Determination of the Content of Ca, Mn, Fe, Cu, Ni, As, Se, Sr, Cd, Ba and Hg in Rice with ICP-MS in the Collision Cell. Journal of Spectroscopy Laboratory, 26, 10951099.

[20] Liu, L.L., Wang, J. and Zhang, L.J. (2009) The Determination of Mercury Content in Fish with Microwave DigestionIsotope Dilution Mass Spectrometry Method. Journal of Beijing University of Chemical Technology, 36, 21-24.

\section{Submit or recommend next manuscript to SCIRP and we will provide best service for you:}

Accepting pre-submission inquiries through Email, Facebook, LinkedIn, Twitter, etc.

A wide selection of journals (inclusive of 9 subjects, more than 200 journals)

Providing 24-hour high-quality service

User-friendly online submission system

Fair and swift peer-review system

Efficient typesetting and proofreading procedure

Display of the result of downloads and visits, as well as the number of cited articles

Maximum dissemination of your research work

Submit your manuscript at: http://papersubmission.scirp.org/ 